\title{
On the Relationship between Social Rank during the Velvet Period and Antler Parameters in a Growing Red Deer Stag
}

\author{
Luděk BARTOŠ, Václav PERNER \& Bohumír PROCHÃZKA
}

Bartoš L., Perner V. \& Procházka B., 1987: On the relationship between social rank during the velvet period and antler parameters in a growing red deer stag. Acta theriol., 32, 24: 403-412 [With 1 Table]

The aim of this study was to assess how social position of a growing red deer stag is related to antler development. 17 stags were observed in the period between 1976-1983. The social position of each stag within the group was estimated during competition for food during the time of antler growth. Social position of each stag was then related to antler size. The majority of antler measurements showed significant correlation with the rank position of the stag. High-ranking stags had heavier, longer and more branched antlers, with more massive main beam between trez tine and royal. Royal or top points were more numerous and longer. The best indicators of high social position during antler growth seemed to be diameters of seal (pedicle attachment point) and coronet, and the composite value of the total antler length. It is concluded that the physiological consequence of the stag's behaviour on the antler growth and the behavioural meaning of his fullgrown size have quite different bases. It depends probably on the social stability of a bachelor group of stags how much the relationship between the rank and antler size will be pronounced. On the other hand, the behavioural meaning of antler size depends on social circumstances and previous experiences.

Department of Genetics, Research Institute of Animal Production, CS-104 00 Praha 10-Uhř́něves (L.B.); East Bohemia State Forest Enterprises, 53842 Ronov nad Doubravou (V.P.); Institute of Hygiene and Epidemiology, 10042 Praha 10 (B.P.), Czechoslovakia]

\section{INTRODUCTION}

The possibility of a relationship between social position and antler size in Cervidae has been widely discussed. However, there is no general agreement on the question regarding the sociobiological value of deer antlers. Some authors have suggested that antlers advertise an individual's dominance status but variable results have been obtained in field studies designed to assess this (short review in Bartoš, 1987). All the studies were based on observations of male deer who had fullgrown antlers. That is, the studies compared the relationship between the male's fighting ability and its attained antler size. During the rutting season, for instance, the fighting ability of individual red deer stags changes as their body condition declines, and individuals vary in timing of their decline. Consequently, a stag that assessed its opponents on criteria that 
did not vary with changes in body condition during the rut make many incorrect decisicns (Clutton-Brock \& Albon, 1979; Clutton-Brock et al., 1982).

Previous studies have suggested that social position and related agonistic activity of stags during the velvet period influence the antler growth so that fullgrown antlers are consequences of previous social position rather than vice versa (Bartoš \& Hyánek, 1982a; 1982b). Also Wölfel (1983) claimed possible role of rank position of a male yearling red deer in antler development. The aim of the present study was to assess in details and more precisely how the social position of a growing red deer stag during the velvet period is related to various measures of parallel antler development.

\section{METHODS}

\subsection{Study Area and Subjects}

The study was carried out between 1972 and 1983 on a "white" red deer population (Bartoš, 1982) living in the Game Reserve Žehušice, Central Bohemia, Czechoslovakia. Observations were performed in the main penned area of the reserve (1.26 square $\mathrm{km}$ ). During the period of observation the number of stags living in the main part of the park fluctuated between three and 18 (details in Bartoš, 1986a). No red deer in the reserve are culled except wild coloured male progeny. The stags were known individually since birth, so that their ages were known with certainty. There were 32 individuals older than two years present in the park during the period of the study but only those stags for which data of at least three seasons were available are involved in the analysis. One stag older than five years at the beginning of the study was also excluded. These restrictions resulted in there being 17 different stags as subjects. The seasons o:er which the data were relevant was the period between 1976-1983. All the stags had the possibility to experience the involved period with the same peers.

Data were available for each stag for a mean ( \pm S.E.) of $3.88 \pm 0.36$ consecutive seasons. Animals were studied from $2.41 \pm 0.21$ years to $5.29 \pm 0.44$ years. When it is stated that an animal had an age of "two years", it means that the antler data were taken for a stag from two years of age onwards. Only four of the 17 stags reached over five years of age.

\subsection{Behavioural Methods}

All the observations of social relationships were taken during artificial feeding which was performed throughout the year as described earlier (Bartoš, 1982). It was presumed that dominance relationships among stags at artificial feeding sites are similar to those seen in stags grazing under natural conditions (Appleby, 1980; Bartoš, 1982). As in the previous studies (e.g. Bartoš, 1986b) the degree of tameness of the animals made it possible to observe them from a point $20-30$ metres away from the food piles by an observer seated on a tractor without 
their behaviour being apparently influenced by the observer. The intervals between individual testing observations were three to four weeks throughout the whole velvet period (the period between the time when the first stag in the season cast his antlers till the time when the last stag in the season shed his velvet), i.e. four to five assessments of the hierarchy were performed for each velvet period. A stag was said to be dominant over another if it displaced it from a food pile on three or more occasions and was not displaced itself. The majority of stags encountered each other repeatedly during each observation session meaning that the rank order could be easily assessed. There were almost no changes in rank position of the stags between observations within the same velvet period. For the analysis the social position of each stag was expressed in the form of a "dominance index" (Bartoš \& Hyánek, 1982a). This index is a relative value $(0-1)$ expressed by dividing the position in the hierarchy (with alpha $=1$, etc.) by the number of stags present in the park. The higher the social rank, the lower the dominance index. The deer established typical linear hierarchy throughout the study.

\subsection{Antler Measurements}

Only cast antlers were used for measurements but not all could be located. The spikes of yearlings were omitted from this study. The terminology of antler characteristics has been adopted from Bubenik (1982a) and/or Whitehead (1982). Where the two authors differ, the term of Bubenik is used and the one of Whitehead is added in parentheses. The following antler characteristics were used for the analysis:

Antler weight - the weight of the entire antler as determined six months after casting;

Antler length - the distance from the coronet to the farthest point of an antler's lateral side;

Lower circumference - the circumference of a main antler beam between brow and trez tines;

Upper circumference - the circumference of a main antler beam between trez tine and royal (tops);

Number of tines - the number of all ends of a beam or a tine longer than $25 \mathrm{~mm}$;

Number of points of the royal (number of tops) - the number of all royal tines;

Brow tine - the length of the tine;

Bez tine - the length of the tine;

Trez tine - the length of the tine;

First point of the royal (first top tine) - the length of the longest royal point;

Second point of the royal (second top tine) - the length of the second longest royal point;

Third point of the royal (third top tine) - the length of the third longest royal point;

All the tines and points were measured from their base to their terminals as is usually done for trophy evaluation (Whitehead, 1982).

Total antler length - the final sum of the length of all tines, points and beams (after Bubenik, 1982a);

Diameter of seal (diameter of pedicle attachment point) - the length of the longest diameter of the seal; 
Diameter of coronet - the length of the longest diameter of the coronet.

In each of the cast antlers presence or absence of two characteristics were registered:

Double royal (double crown fork) - a special type of royal derived from the forklet shape in two stages;

Wapiti shape - the type of the architecture of the royal characterised by back tine occurrence usually seen in North American elk (C. e. canadensis).

The above presented antler measurements and characteristics were used as means of both antlers.

\subsection{Statistics}

In red deer, antler growth is primarily related to age, indeed from the first to the fifth set of antlers there is an uninterrupted gain of antler size. After the completion of body development, there is great variation between individuals (Huxley, 1931; Flock, 1970; Bubenik, 1982c). The antler growth has been simplified into a model that antlers increase linearly during a stag's ontogeny up to five years of age, while afterwards there is no regular increase (the same pattern has been found also in a red deer stag's social position by Appleby, 1980 and Bartoš and Hyánek, 1982a). According to the advanced model, a linear regression of growth of all the antler measurements and dominance indices was estimated for each stag. Then the values for two extremes of a stag's ontogeny were calculated (two years - the beginning of the first branched antler growth, and five years - the end of body development). Such calculated values of the dominance indices were correlated with those of antler measurements.

\section{RESULTS}

Values of correlation coefficients between dominance index and antler characteristics for both age categories are shown in Table 1. All the antler characteristics but two (lower circumference and double royal) showed significant negative correlations with dominance index for two as well as five year old stags. This means that the higher the rank position of a stag, the larger is the produced antler. The highest values appeared in the diameter of seal, total antler length and diameter of coronet.

\section{DISCUSSION}

Results of this study have indicated a correlation between the social position of a growing stag during the velvet season and size of the developing antlers. There were very similar values of correlation coefficients both in juvenile (2-year-old) and mature (5-year-old) stags. In brief, high-ranking stags had heavier, longer and more branched antlers, with more massive main beam between bez and trez tines. Royal and 
top points were more numerous and longer. The best indicator of high social position during antler growth seemed to be diameters of seal (pedicle attachment point) and coronet, and the composite value of the total antler length. The base of antlers has been already shown to be important mechanically in their design (Kitchener, 1985). "White" stags of high status were characterised by a royal structure similar to that seen in the North American elk. One may speculate whether the wapiti shape occurrence is the result of possible previous interspecific hybridi-

Table 1

Correlation coefficients between dominance index and antler characteristics.

\begin{tabular}{lcc}
\hline $\begin{array}{c}\text { Antler } \\
\text { characteristic }\end{array}$ & $\begin{array}{c}\text { Coefficients for } \\
\text { 2-year-old stags }\end{array}$ & $\begin{array}{c}\text { Coefficients for } \\
\text { 5-year-old stags }\end{array}$ \\
\hline $\begin{array}{l}\text { Antler weight } \\
\text { Antler length }\end{array}$ & $-0.82^{* *}$ & $-0.77^{* *}$ \\
Lower circumference & $-0.82^{* *}$ & $-0.82^{* *}$ \\
Upper circumference & $-0.81^{* *}$ & $-0.40^{* *}$ \\
Number of tines & $-0.59^{*}$ & $-0.57^{*}$ \\
Number of points of the & $-0.79^{* *}$ & $-0.79^{* *}$ \\
royal (tops) & $-0.87^{* *}$ & $-0.86^{* *}$ \\
Brow tine & $-0.85^{* *}$ & $-0.83^{* *}$ \\
Bez tine & $-0.83^{* *}$ & $-0.82^{* *}$ \\
Trez tine & $-0.83^{* *}$ & $-0.84^{* *}$ \\
$\begin{array}{l}\text { First point of the royal } \\
\text { (top tine) }\end{array}$ & $-0.86^{* *}$ & $-0.86^{* *}$ \\
$\begin{array}{l}\text { Second point of the royal } \\
\text { (top tine) }\end{array}$ & $-0.85^{* *}$ & $-0.82^{* *}$ \\
$\begin{array}{l}\text { Third point of the royal } \\
\text { (top tine) }\end{array}$ & $-0.89^{* *}$ & $-0.86^{* *}$ \\
$\begin{array}{l}\text { Length of all royal points } \\
\text { (tops) }\end{array}$ & $-0.92^{* *}$ & $-0.92^{* *}$ \\
Total antler length & $-0.93^{* *}$ & $-0.92^{* *}$ \\
$\begin{array}{l}\text { Diameter of seal (pedicle } \\
\text { attachment point) }\end{array}$ & $-0.92^{* *}$ & $-0.91^{* *}$ \\
$\begin{array}{l}\text { Diameter of coronet } \\
\text { Double royal (crown fork) }\end{array}$ & -0.46 & -0.43 \\
Wapiti shape & $-0.55^{*}$ & $-0.54^{*}$ \\
\hline
\end{tabular}

${ }^{*} p<0.05,{ }^{* *} p<0.01$

zation since there were some imports of wapities to the park (Hahn, 1881). On the other hand, wapiti-form, which is an evolutionary advanced form of antlers may be of old origins. Eastern European deer occasionally show the wapiti-type antlers, namely from Holocene fossil records (Geist, 1986 - personal communication).

The presented conclusions seem to be contrary to conclusions of some other authors. For example Clutton-Brock et al. (1982) have argued that antler size is related to individual difference in body size and weight. To support it, there is a large body of evidence for a relationship between 
body size and weight in red deer and antler weight (Huxley, 1926; 1931; Hyvärinen et al., 1977; Clutton-Brock et al., 1979; 1982; Appleby, 1982). No body weight data of "white" stags were available but there seemed a tendency for visually heavier stags to achieve higher rank. On the other hand, at the top hierarchy, a relationship to weight was not obvious. Although the average age of the stags present in the studied population is very low for many years, the alpha stag was not usually the oldest (and hence the heaviest?) individual (Bartoš, 1986a). In 1983, for example, the alpha position was held by a 4 -year-old stag who was estimated to be the seventh largest animal of the population of 14 stags. The possible role of body weight in the relationship between rank position and antler growth have been somehow eliminated by the statistical control of age in the present study. The observed stags were of the age between two and five years. That is the period of the ontogeny when exists dependence of body weight on age and also of rank position (Appleby, 1980; Bartoš \& Hyánek, 1982a). In the parallel study in which the body weight of the observed deer could be estimated at least for one season, rank position of the stags was correlated with their body weight. Nevertheless, while the rank position showed correlation with the antler size, the body weight did not (Bartoš et al., 1988). Similarly, in Scotland Suttie (1980a) observing farmed stags of ages (four and five years) resembling the age of the stags in the present study found that live body weight did not correlate with antler weight in his experimental deer group. In a further paper he (Suttie, 1985) suggested that dominance in adult stags influenced body weight rather than vice versa.

Close correlation between social dominance and levels of some hormones have been reported in mammals. The dominant position often tends to be related to elevated levels of androgens while subordinate status seems to be associated with decreased hormone secretion and by increasing levels of glucocorticoids (e.g. Brain, 1980; Leshner, 1980). The possible hormonal basis and feedback relationships between rank position of a male deer and his antler growth has been discussed in details elsewhere (Bartoš, 1987). Experiments with captive red deer stags also indicate an essential, prevailing role of nutrition in antler growth (Vogt, 1947; Suttie, 1980b). The behaviour/hormonal relationships thus may only apply to well nourished populations such as the present "white" red deer herd which has been subject to artificial feeding on a daily basis.

It must be also emphasized that the dominance index is based on both rank position and the number of stags present. The number of stags is likely to modulate the level of aggressive behaviour within the social group. The more stags are present, the higher stimulation of top- 
ranking stags, and the greater suppression of the bottom-ranked stags (Bartoš, 1986b).

The living conditions in Žehušice differ in several ways from those elsewhere. The bachelor group of stags is constant throughout the year. The same animals encounter each other the whole year round. This resulted in a very stable social hierarchy. Social status remained almost constant even after antler casting or antler breakage (Bartoš, 1986a). It is little wonder, then, that there is also a close correlation between rank position and antler length, weight and the number of tines found outside the velvet period (Bartoš \& Hyánek, 1982b). In feral populations, reduction in gregariousness immediately after antler casting is known among red deer stags (Linke, 1957; Raesfeld \& Vorreyer, 1964; Lincoln et al., 1970; Gossow, 1971; Bützler, 1974; Geist, 1982). This may result in a less pronounced general relationship between rank position and antler size. Even under the conditions of limited space, as in the Žehusice deer park, the bachelor group of stags tends to disintegrate (Bartoš, 1985; Bartoš \& Perner, 1985). In a parallel study we followed the distribution of all stags in social groups during the period between antler casting and cleaning. The resulting estimation of such a relative rank position differed from general rank within the whole bachelor group. The relative rank position also showed closer correlation with fully grown antlers than did the general rank position (Bartoš, 1987).

Before the rut bachelor groups of the feral populations completely disintegrate and stags disperse widely (Darling, 1937; Lincoln et al., 1970; Bützler, 1974; Clutton-Brock et al., 1982). During the rutting season, strange stags may be encountered. The sexual competition during that time results in a strong motivation for fighting. This may help stags to overcome a possible negative experience with bachelor group members during the antler growth period so that interactions with larger antlered individuals are not avoided. Besides, during the rutting season, additional display symbols and characteristics come into use (Lincoln, 1972) These factors may explain why e.g. Clutton-Brock et al. (1979) failed to find any simple correlation between success in rutting fights and antler size. After the rut, stags usually return to their original ranges (Lincoln et al., 1970; Bützler, 1974; Clutton-Brock et al., 1982). Winter groups thus generally consist more or less of stags which had been present during the antler development. Hence Appleby (1982) studying the same population as Clutton-Brock et al. (1979) was able to detect at least partly some relationships between rank and antler characteristics in his winter observations.

In conclusion, the more dominant a male deer during the period of antler development, the more fully expressed his antlers are. Then the 
behavioural meaning of these antlers depends probably on social background of the studied population and previous experience of the male. Hence there is a number of studies suggesting no consistent tendency for males to avoid fighting individuals with larger antlers at least in red deer (Lydekker, 1898; Krzywiński, 1978; Clutton-Brock et al., 1979; 1982; Appleby, 1982), whilst under some circumstances there is evidence of an advantage to bear large antlers (Bubenik A., 1982b; Bartoš and Hyánek, 1982b).

Acknowledgements: The authors would like to thank Drs. P. F. Brain, A. B. Bubenik, G. A. Bubenik, T. H. Clutton-Brock and V. Geist for their helpful comments on earlier drafts of the manuscript and G. K. Whitehead for his comments on antler characteristics terminology. The authors give extra thanks to Dr. Brain for his help with the preparation of the English version of the manuscript.

\section{REFERENCES}

1. Appleby M. C., 1980: Social rank and food access in red deer stags. Behaviour, 74: 294-309.

2. Appleby M. C., 1982: The consequences and causes of high social rank in red deer stags. Behaviour, 80: 259-273.

3. Bartoš L., 1982: Reproductive and social aspects of the behaviour of "white" red deer, Säugetierkundl. Mitt., 30: 89-117.

4. Bartoš L., 1985: Social activity and the antler cycle in red deer stags. [In: P. F. Fennessy \& K. R. Drew (eds.) "Biology of deer production"]. Roy. Soc. N. Z. Bull. 22: 269-272.

5. Bartoš L., 1986a: Relationships between behaviour and antler cycle timing in red deer. Ethology, 71: 305-314.

6. Bartoš L., 1986b: Dominance and aggression in various sized groups of red deer stags. Aggress. Behav., 12: 175-182.

7. Bartoš L., 1987: Social status and antler development. [In: G. A. Bubenik \& A. B. Bubenik (eds.) "Antlers, pronghorns and horns"|. Perspectives in Vertebrate Sciences, Vol. 1, Dr. W. Junk Publishers: (in press), The Hauge.

8. Bartoš L. \& Hyánek J., 1982a: Social position in the red deer stag. I. The effect on developing antlers. [In: R. D. Brown (ed.) "Antler development in Cervidae"]. Caesar Kleberg Wildl. Res. Inst: 451-461, Kingsville.

9. Bartoš L. \& Hyánek J., 1982b: Social position in the red deer stag. II. The relationship with developed antlers. [In: R. D. Brown (ed.) "Antler development in Cervidae"]. Caesar Kelberg Wildl. Res. Inst: 463-466, Kingsville.

10. Bartoš L. \& Perner V., 1985: Integrity of a red deer stag social group during velvet period, association of individuals, and timing of antler cleaning Behaviour, 95: 314-323.

10a. Bartoš L., Perner V. \& Losos S., 1988: Red deer stags rank position, body weigth and antler growth. Acta theriol., in press.

11. Brain P. F., 1980: Adaptive aspects of hormonal correlates of attack and defence in laboratory mice - a study in ethobiology. [In: P. S. McConnell, G. J. Boer, H. J. Romijn, N. E. Vandepoll \& M. A. Corner (eds.) "Adaptive capabilities of the nervous system"]. Elsevier North-Holland Biomedical Press: 391-413. Amsterdam.

12. Bubenik A. B., 1982a: Proposal for standardized nomenclature for bony appendices in Pecora. [In: R. D. Brown, (ed.) "Antler development in Cervidae"], Caesar Kleberg Wildl. Res. Inst: 187-194, Kingsville. 
13. Bubenik A. B., 1982b: The behavioral aspects of antlerogenesis. [In: R. D. Brown (ed.) "Antler development, in Cervidae"]. Caesar Kleberg Wildl. Res. Inst: 389-449, Kingsville.

14. Bubenik A. B., 1982c: Physiology. [In: J. W. Thomas \& D. E. Toweill (eds.) "Elk of North America, ecology and management"J. Stackople Books: 125-179, Harrisburg.

15. Bützler W., 1974: Kampf- und Paarungsverhalten, Soziale Rangordung und Aktivitätsperiodik beim Rothirsch. Beiheft Z. Tierpsychol. No. 16, Paul Verlag, Hamburg, Berlin.

16. Clutton-Brock T. H. \& Albon S. D., 1979: The roaring of red deer and the evaluation of honest advertisement. Behaviour, 69: 145-170.

17. Clutton-Brock T. H., Albon S. D., Gibson R. M. \& Guinness F. E., 1979: The logical stag: Adaptive aspects of fighting in red deer (Cervus elaphus L.). Anim. Behav., 27: 211-225.

18. Clutton-Brock T. H., Guinness F. E. \& Albon S. D., 1982: Red deer, behaviour and ecology of two sexes. The University of Chicago, Edinburgh Univ. Press, Edinburgh.

19. Darling F. F., 1937: A herd of red deer. Oxford Univ. Press, Humphrey Milford, London.

20. Flook D. R., 1970: Causes and implications of an observed sex differential in the survival of wapiti. Can. Wildl. Serv. Bull. Rep. Ser. 11. Can. Wildl. Serv., Ottawa.

21. Geist V., 1982: Adaptive behavioral strategies. [In: J. W. Thomas \& D. E. Toweill (eds.) "Elk of North America, ecology and management"]. Stackpole Books: 219-277, Harrisburg.

22. Gossow H., 1971: Soziologische und Rangordungaspekte bei einer alpinen Rotwildpopulation. Allg. Forstztg., 7: 169-173.

23. Hahn M., 1881: Weisses Edelwild. Centralblatt Gesamm. Forstwes., 7: 81-82.

24. Huxley J. S., 1926: The annual increment of the antlers of the red deer (Cervus elaphus). Proc. Zool. Soc. Lond., 67: 1021-1036.

25. Huxley J. S., 1931: The relative size of antlers in deer. Proc. Zool. Soc. Lond., 19: $819-863$

26. Hyvärinen H., Kay R. N. B. \& Hamilton. W. J., 1977: Variation in weight, specific gravity and composition of antlers of red deer (Cervus elaphus L.). Brit. J. Nutr., 38: 301-311.

27. Kitchener A., 1985: The effect of behaviour body weight on the mechanical design of horns. J. Zool., 205: 191-203.

28. Krzywiński A., 1978: Obserwacje nad sztucznym rozrodem jelenia szlachetnego (Cervus elaphus L.). Ph. D. Thesis, Institute of Genetics and Animal Breeding, Pol. Acad. Sci., Popielno.

29. Leshner A. I., 1980: The interaction of experience and neuroendocrine factors in determining behavioral adaptations to aggression. [In: P. S. McConnell, G. J. Boer, H. J. Romijn, N. E. Vandepoll \& M. A. Corner (eds.) "Adaptive capabilities of the nervous system"'. Elsevier North-Holland Biomedical Press: 427-438, Amsterdam.

30. Lincoln G. A., 1972: The role of antlers in the behaviour of red deer. J. Exp. Zool., 182: 233-250.

31. Lincoln G. A., Youngson R. W. \& Short R. V., 1970: The social and sexual behaviour of the red deer stag. J. Reprod. Fert., Suppl., 11: 71-103.

32. Linke W., 1957: Der Rotrisch. Die neue Brehm-Bucherei No. 129. A. Ziemsen Verlag, Wittenberg-Lutherstadt. 
33. Lydekker R., 1898: The deer of all lands. Rowland Ward, London.

34. Reasfeld F. \& Vorreyer F., 1964: Das Rotwild-Naturgeschichte Hege und Jagd. Paul Parey Verlag, Hamburg, Berlin.

35. Suttie J. M., 1980a: The effect of antler removal on dominance and fighting behaviour in farmed red deer stags. J. Zool., 190: 217-224.

36. Suttie J. M., 1980b: Influence of nutrition on growth and sexual maturation of captive red deer stags. [In: E. Reimers, E. Gaare \& S. Skjenneberg (eds.) "Proc. 2nd Int. Reindeer/ Caribou Symp."] Røros: 341-349, Trondheim.

37. Suttie J. M., 1985: Social dominance in farmed red deer stags. Appl. Anim. Behav. Sci., 14: 191-199.

38. Vogt F., 1947: Das Rotwild. Wien.

39. Whitehead G. K., 1982: Hunting and stalking deer throughout the world. B. T. Batsford Ltd., London.

40. Wölfel H., 1983: Zur Jugentwicklung, Mutter-Kind-Bindung und Feindvermeidung beim Rothirsch (Cervus elaphus). Z. Jadgwiss., 29: 143-162.

Received 10 February 1987, Accepted 14 May 1987.

Luděk BARTOŠ, Václav PERNER i Bohumir PROCHÁZKA

JAKOSC POROŻA A POZYCJA SOCJALNA BYKOW JELENI

\section{Streszczenie}

Celem badań było ustalenie na ile pozycja socjalna dojrzewających byków jelenia wplywa na rozwój poroża. Siedemnaście byków obserwowano w latach 1976-1983. Miejsce każdego byka w hierarchii socjalnej określano na podstawie obserwacji konkurencji o pokarm w czasie wzrostu poroża. Socjalna pozycja każdego byka była następnie korelowana z ostateczną wielkością poroża. Dominujące samce tworzyły poroża cięższe, dłuższe i bardziej rozbudowane, z koronami o liczniejszych i dłuższych odnogach.

Najlepszym wskaźnikiem rangi socjalnej byka w okresie wzrostu poroża okazała się średnica róży, średnica pnia (w miejscu przyrastania tyk) oraz sumaryczna długość wszystkich odnóg poroża (Tabela 1). 